\title{
Replies to Michela Bella, William Curtis, and Emil Višňovský
}

Rosa M. Calcaterra

\section{(2) OpenEdition}

1 Journals

Electronic version

URL: http://journals.openedition.org/ejpap/2203

DOI: 10.4000/ejpap.2203

ISSN: 2036-4091

Publisher

Associazione Pragma

Electronic reference

Rosa M. Calcaterra, « Replies to Michela Bella, William Curtis, and Emil Višňovský », European Journal of Pragmatism and American Philosophy [Online], XII-2 | 2020, Online since 14 December 2020, connection on 15 December 2020. URL : http://journals.openedition.org/ejpap/2203 ; DOI : https:// doi.org/10.4000/ejpap.2203

This text was automatically generated on 15 December 2020.

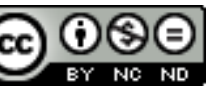

Author retains copyright and grants the European Journal of Pragmatism and American Philosophy right of first publication with the work simultaneously licensed under a Creative Commons AttributionNonCommercial-NoDerivatives 4.0 International License. 


\title{
Replies to Michela Bella, William Curtis, and Emil Višňovský
}

\author{
Rosa M. Calcaterra
}

1 I am very grateful to Michela Bella, William Curtis, and Emil Višňovský for their thorough and generous interventions on my latest work. I would also like to thank EJPAP's executive editors, Roberta Dreon and Sarin Marchetti, for hosting a symposium on this book and Michela Bella for her editorial work. Each of the three contributions to the symposium grasps some key features of my work, indeed the spirit that animated it, even if, at times, my statements are not entirely explicit. Since the criticisms are especially generous towards my theoretical commitment, I consider the three contributions as an exemplary testimony to the dialogical form of philosophical discussions, so recommended by Rorty.

2 Michela Bella's intervention reconstructs the chapters of my book in detail, and I appreciate her ability to explain my intentions and theoretical choices. Bella immediately grasps the work's overall focus, which is the interest in "the practical and ethical aspects of Rorty's contingency," which runs parallel to my invitation to build "a new pragmatist anthropology that goes beyond Rorty." I have always cultivated a specific interest in philosophical elaborations' practical and ethical implications, even the more abstract ones. In my work, I address such issues as realism, representationalism, and foundationalism; the development of the criterion of justification in scientific research practices; the relationship between mind and body; and between normative and descriptive. Working within the specific field of epistemology, I have tried to show how all this always involves some stance on humans' image, their potential, their limits, and, consequently, on the tools and projects that may appear more appropriate to their existence. All these issues find in Rorty's contingentism, the theoretical background of an ethic of philosophy. This ethic tries to remind the philosopher of his responsibility as a social actor, rather than as an aristocratic spectator of essences of truth, right, and beauty - to paraphrase James, one of Rorty's most beloved authors. Such a vision has circumscribed a series of "ethically qualifying concepts," such as dialogue, the conversation of humanity, and solidarity - 
as Bella notes. I believe that the epistemological choices to move from the foundation to the justification of philosophical or scientific assertions, from the epistemic centrality of the knowing subject to the construction of an informed consensus among the subjects who practice the search for knowledge, belong to the range of ethical criteria. To sum up, there is an epistemological choice that aims to replace the search of certainty - stigmatized by Dewey and Wittgenstein - with the exercise of Socratic irony. Indeed, Rorty's ironic attitude closely resembles the Socratic irony that imposes itself at the origins of philosophy and authenticates its radically human meaning, leaving the possession of absolute and immovable truths to the Gods or other extrahuman authorities stigmatized by Rorty.

3 Bella skillfully dwells on the difference between "progress" and "change" in philosophy, which I pointed out as an essential aspect to clarify the socially active and deeply ethical role that Rorty attributes to philosophical discourse. Talking about changes rather than philosophical progress means setting aside the criterion implicit in the latter concept - i.e., the idea that there is a fixed final goal of philosophical work. The aim is to emphasize instead the philosopher's responsibility of "uncovering the tacit presuppositions" underlying our vocabularies and assertions, including the more formal or specialized ones. At the same time, this means gathering Dewey's lesson that philosophical reflection "contributes to understanding the emergence of new problems" or to reconstructing the "problematic situations" that set the humans' paths through new vocabularies. Indeed, for Rorty, recovering the ancient ethical task of philosophy means enhancing its potential as a human tool for human life. It is up to us to know how to build and use it in ways that seem more appropriate to what the uncertainty of events requires. Thus, Dewey's call to revitalize philosophy's ethicalpolitical function developed into Rorty's invitation to use philosophy as a "critique of culture," and I believe his critique of traditional realist and foundationalist epistemologies finds its proper place in such an invitation.

Concerning Rorty's relationship with Dewey and James, Bella poses two critical questions to which I can only partially answer. The first question concerns the theme of anti-realism, the other concerns the evaluation of emotions. On the first point, I would answer that there are differences, but perhaps they are not irreconcilable. Even Dewey and James, no less than Rorty, support a distance from metaphysical realism, instead promoting what can be defined as "pragmatic realism," that is, a realism entrusted to the functioning of our assertions on reality in terms of "regional" responses to the problems that arise. I use the term "regional" to say that this perspective sets aside the idea of a real universe that encompasses particular realities, according to systematic relationships in terms of space and time, and for which we should prepare perspicuous "representations" capable of reflecting the constitutive and eternal features of this universe. The idea of "pluriverse" adopted by James and Dewey's instrumentalism goes in this direction. Both these perspectives privilege the role of the specific problematic situations we confront in the concreteness of scientific and philosophical investigation, instead of searching for metaphysical constructions that give us the "essential," eternal and predetermined components of the real universe. The construction of "essentialist" metaphysics is, in fact, unsustainable in a post-Darwinian climate in which it is impossible to avoid embracing contingency - which here means anti-determinism, the dynamism of reality and human transactions with it. Additionally, both James and Dewey emphasize the importance of these transactions as moments of inception and, at the same time, verification of our assertions about reality. I am referring to the 
virtuous circle that both authors establish between the knowing subject and the real world through their renewed concept of experience. They synthesize in the notion of "experience" empirical and conceptual factors according to a relationship of mutual functionality. My conviction is that in substance, Rorty shares the pragmatic realism of James and Dewey. He refuses, however, to deepen the interference between empirical and conceptual planes, both because he rejects the very concept of experience as a philosophical instrument and because he is all too concerned with maintaining a precise distance between the physical-natural and the mental plane. For he is convinced that their combination leads to the "bad" metaphysics of reductionist naturalism.

5 On the other hand, like Peirce, Dewey and James renounce neither the idea of reality as an epistemological presupposition nor as a regulatory idea of our cognitive practices $\grave{a}$ la Kant. It is on this latter aspect that the distance from Rorty is most marked. Rorty openly rejects both these versions of the concept of reality, believing them to be a legacy of foundational epistemology, in any case, superfluous compared to cognitive practices. In this regard, I cannot entirely agree with Rorty, and I believe that his concern to zero out realist vocabulary often has the upper hand. This concern prevents him both from embracing in his "linguistic pragmatism" the novelties that James and Dewey had brought to this same vocabulary and from grasping an important meaning of the concept of a "regulatory idea." Starting from Kant, the latter means a criterion of aggregation of our cognitive and valuing practices. It would have been essential to consider James' revalidation of the conceptions of knowledge as correspondence. In this context, James states that we must not abandon the reference to the "facts" of reality. Instead, we should stop considering the two poles of the cognitive relationship - the subject and the reality - as static and ontologically opposed entities, to treat them instead as the components of a process whose results must be commensurate with their ability to contribute to the success of our actions.

Bella asks if Rorty would have accepted James' response to the "misunderstanding" for which he was attributed an anti-realist position. I think he could have subscribed to it as far as it would be contradictory to speak of pragmatism (no matter how "neo" he wants it to be) excluding pragmata - i.e., excluding inter-subjectively recognizable "facts" and "actions." However, to Rorty, given his insistent battle against realist epistemologies, it would perhaps have seemed compromising to declare his approval of James' realism. Instead, I believe that a "pragmatic realism" enriched by the Rortyan emphasis on linguistic practices would have benefited not only from a deepening of Dewey and James' particular realist vein but also from what I have elsewhere called Mead's "social realism" (cf. Calcaterra 2003). I have tried to show that, despite Rorty's much-acclaimed anti-realism, his position includes a tacit assent to the idea that our assertions must have some connection to what we ordinarily attribute to the "real facts." Nevertheless, it is true that he merely takes this link for granted, just as he prefers to "practice," without adequately arguing, the functional relationship between the descriptive and normative planes, both in epistemology and ethics.

7 I focused on the answer to Bella's first question because I reserve the right to return to the second - the theme of emotions - in answering to Višňovský's intervention. I will limit myself to saying that Rorty did not give enough space to emotions because he considered them a theme philosophically compromised by traditional intuitionism, which regards them as an absolutely private field and accessible only by immediate and 
strictly subjective means. This view contrasts with the intention of Rorty's pragmatism, which instead focuses on the public nature of linguistic practices. Emotions probably appeared to Rorty too interwoven with psychologism, which, in his view, implied the encroachment of psychology into philosophy, thus entailing the risk of naturalist foundationalism.

In the introduction to his comments, Emil Višňovský writes that "Rorty's philosophy still needs explications" and then points out my "attempts at blending pragmatism with analytic philosophy" as one of the ways in which I try to benefit from the challenges that the New York philosopher has brought to our attention. I would like to point out that the term "challenges," appearing in my work's subtitle, means that the vis polemica so characteristic of Rorty's writings, sometimes deliberately exasperated, should be taken seriously and not as a mere provocation by a "bad boy" of philosophy. From this point of view, I found it inevitable to highlight the continuity between pragmatism and analytic philosophy in the construction of Rorty's thought, as Višňovský points out, starting from observing the cultural role he assigns to philosophy. The idea that philosophy is a factor of cultural-historical processes is clearly expressed in the battle carried out by classic authors of pragmatism against abstractionism and intellectualism of various kinds, primarily those found throughout much of traditional philosophy. Alternatively, these authors made a strong appeal to turn attention to the importance of the interplay between human ideas and practices, between philosophy and concrete ethical orientations - social and individual. On the other hand, analytic philosophy was also born to counteract the verbalisms and conceptual ambiguities of metaphysics and as a tool for science and philosophy to interact on the field of analysis of language and its meanings.

9 A glimpse at Rorty's biography reveals the influence of the pragmatist mentality in the early years of his education, both in the family and at university. Nevertheless, his university studies focused on analytic philosophy, which Rudolf Carnap introduced him to. Despite the common opinion on Rorty as an analytic philosopher who "converts" himself to pragmatism, I believe that we should instead talk about a path that goes from pragmatism to analytic philosophy and returns to pragmatism. It is a return innervated by the criticism of the neopositivist strands of this movement of thought and the so-called "post-neopositivist" turning point that characterized analytic philosophy since the Sixties. It is not by chance that post-neopositivism gave prominence to the link between language and praxis, the criteria of sociality/intersubjectivity, action and dynamism of thought and language. That is, to criteria also shared by pragmatist philosophies, both on the epistemological and ethical levels. The interests and philosophical themes shared by pragmatism and analytic philosophy indeed entailed different directives but remain susceptible to integration.

10 Many years before I started researching Rorty's challenges to our philosophical climate, I organized a volume of essays on the relationship between pragmatism and analytic philosophy, which aimed to deepen the thematic similarities between these two strands of thought without failing to point out methodological and theoretical differences (Calcaterra 2011). The overall result of this volume, which was unprecedented in Italy and perhaps also in Europe, was very positive, thanks to the valuable quality of the essays that comprise it. This outcome encouraged me to continue comparing the works of some representative authors from both theoretical sides. My main interest was to clarify or make explicit the objectives and socio- 
anthropological effects of some eminent expressions of these two ways of doing philosophy. In both traditions, I could find fruitful elements to increase awareness of philosophy's value as an activity supporting the individual and social-human path.

11 As already said, I have always been convinced that every philosophy or epistemological theory implies some philosophical anthropology or some image of the human being. This image is interesting or even necessary to make explicit, especially where the reference to the human subject's constitution seems non-existent. In comparison with pragmatism, many technicalities of analytic philosophy seem to set aside the anthropological theme altogether. Nevertheless, this philosophical orientation has the indisputable merit of bringing verbal and symbolic language to the forefront. Language can be considered the only and true species-specific characteristic of humans. The last chapter of my book is precisely an attempt to trace on this basis the lines of a "new pragmatic anthropology," distilling the elements of Rorty's work that seem to be engaging in this regard and that I have tried to develop also beyond Rorty.

Getting back to the "continuity" between pragmatism and analytic philosophy in Rorty, I am interested in underlining that, as Peirce and Dewey taught, talking about continuity does not mean talking about linear repetition or the possible mutual reduction of one thing to another, nor the absence of differences. In the case of philosophical reflection, it is rather a matter of looking beyond the philological acrimony to enucleate common interests without disregarding different theoretical and methodological tones.

13 My intense collaboration with Rosaria Egidi favored my research in Wittgenstein's work. This author was pivotal for my reflection on some possible connections with pragmatic arguments and then formed the background to my effort to read Rorty's relationship with analytic philosophy in a less oppositional light than usual. My proposal to make Rudolf Carnap's influence on the neo-pragmatist philosopher explicit also benefits from Wittgenstein's importance in my theoretical research. Emil Višňovský points out my considerations on the similarities between Rorty and Carnap. In these considerations, I tried to highlight the affinity of the "descriptive semantic" and the theory of "linguistic frameworks," elaborated by Carnap, with Rorty's critique of empirical foundationalism and with his deflationist approach to the concept of truth. It is no coincidence that these aspects of Carnap's view were influenced by Wittgenstein, one of Rorty's principal reference authors in constructing his linguistic pragmatism. In Philosophy and the Mirror of Nature, Rorty criticizes Carnap for reiterating the metaphysical distinction between propositional knowledge and knowledge by acquaintance. However, I believe that this criticism should be ascribed to the sort of anti-foundationalist obsession that has unfortunately undermined several Rortyan philosophical assessments. Despite Rorty's reading, I believe that Carnap's distinction should be incorporated into his theory of "linguistic frameworks" aiming to replace foundationalist representationalism with the semantic analysis of notions such as "truth," "reality," and "reference." This comparison would deserve further investigation and could contribute to better understanding the positive evaluation that Rorty reserves to the post-neopositivist strand of analytic philosophy, or what he calls "epistemological behaviorism." It is interesting to remember that, many years after the publication of Philosophy and the Mirror of Nature, Rorty confessed that he would have liked to rewrite most of this book, except the section dedicated to "epistemological behaviorism," which he continued to appreciate. 

favors his lively dialogue with Donald Davidson rather than Dewey's influence. I agree with this reading and would just like to add a few clarifications. I am particularly interested in remembering that Rorty's criticism of the Deweyan concept of experience aimed at eliminating the metaphysical residues he attributed to the Dewey of Experience and Nature and thus avoiding the so-called "metaphysics of the subject" of Cartesian heritage. According to Rorty, the latter survived in Dewey's reference to the "private" and immediate (or non-linguistic) aspect of human reality. From this point of view, Rorty would be right to say that the concept of experience is all too ambiguous precisely because it cannot tell us much of anything useful or shareable in terms of shared linguistic practices. In the book, I defend a non-metaphysical notion of this concept that, in my opinion, constitutes one of the most interesting novelties of Deweyan thought for at least two reasons. First, it is deeply reshaped in the transactional sense; second, because this notion falls within a "cultural naturalism" that tends to circumscribe the private-immediately-ineffable element involved in the metaphysical concept of experience. In this sense, Dewey's analysis of the aestheticemotional sphere is decisive because he attempts to eliminate the metaphysical presupposition of emotions' ineffability, linking them instead to the interactive relationship between the human subject and the physical-natural sphere. I agree with Višňovský when he argues that it is necessary to deepen "the relations between linguistic practices and non-linguistic elements of reality," as he himself did in many important philosophical papers. However, it is not yet clear to me to what extent it is possible to speak of "experience" without resorting to the linguistic-conceptual tools at our disposal. Perhaps also on this point, as Rorty would say, we need new vocabularies. In those currently in use, I can mainly find a generic reference of the concept of experience either to the sensory apparatus or to the phenomenological "experience." However, phenomenologists cannot proceed without a linguistic decoding of experience. In any case, I am convinced that it would be unfair to attribute to Rorty an underestimation of the physical-natural factors of human life. Although he never considered naturalism as a sort of "philosophia prima" to reduce the whole human reality, he never hesitated to join the ranks of naturalists.

William Curtis focuses his stimulating intervention on the questions that my book indirectly raises about the possible interpretations of Rorty's political thinking, which has provoked a rather lively debate. Therefore, Curtis urges me to take a position in this debate and evaluate the interpretations of Robert Brandom and Richard Shusterman. My preliminary statement that I want to leave this aspect of Rorty's work aside seems to Curtis a legitimate choice but not fully realized. I have devoted a few pages to Rorty's intervention on feminism, where I touched on Nancy Fraser's criticism of the form of liberalism he proposes; moreover, I have touched on the theme of liberal democracy in several chapters. In honesty, there were three reasons for not addressing Rorty's political thinking to a sufficiently large extent. The first, and fundamental, consists in the fact that I am not a philosopher of politics in the strict sense of the word; that is to say, I do not think I have the necessary technical skills to make a discourse appropriate to the epochal urgency of a debate on liberalism. In short, it seemed more appropriate to focus on the theoretical aspects, which I believe have a practical and ethical scope, and therefore a necessarily political fallout in the broad sense. The second reason is closely related to the first and concerns my belief in the political value of reflection and philosophical discourse as such. I want to add that one 
does politics when practicing reflection and philosophical discourse, simply because every reflection and discourse tends to be public, directed to people who, willingly or not, live a polis, no more or less than those who make philosophy. I would say with Peirce - who is often hastily judged as the least "political" character of pragmatism that even when we talk to ourselves, we implicitly address someone else. In short, even the so-called inner monologue is a dialogue - the so-called Peirce's "Tuism." The third and final reason for my choice not to deal expressly with Rorty's political thinking is that his pronouncements on this level do not adequately reflect the ethical quality of his philosophical discourse.

However, I try to answer Curtis's crucial question: "Can Rorty be labeled as a 'pragmatic classical liberal"'? My idea is that this label can be legitimate if used in the sense that Richard Posner adopts it, i.e., as the title of a liberal position closer to John Stuart Mill than to Hayek and that, in any case, embraces relativism and skepticism. In other words, I consider this label acceptable as long as one takes seriously into account the emphasis of Rorty's neo-pragmatism on the ironic attitude to which he associates his political vision: an attitude that, roughly speaking, corresponds to his contingent antifoundationalism. I do not believe that the classical forms of liberalism could accommodate irony in Rorty's established sense. At the same time, I doubt that Rorty's irony and anti-foundationalism can be considered skeptical expressions excluding once and for all the notion of foundation. There is a conceptual difference, and therefore also a practical one, in considering "foundation" in aprioristic and static terms or considering it instead as a logical and practical supporting ground historically developed, and which operates concretely in our cognitive and ethical-political practices. In this second meaning, which I would call "contingentist" for brevity's sake, there is no presumption that there is a reality behind such practices and their intrinsic linguisticity. This does not mean, however, that our practices are evanescent or entrusted to mere chance. Instead, the contingentist meaning of the notion of "foundation" recalls the centrality of the pragmata in the construction of epistemic and value criteria and, at the same time, underlines the fact that they - precisely because of their contingency - are modifiable. We should understand the couple of irony and antifoundationalism presented in Rorty in this light. Therefore, it is correct to speak of his contingentism as the opening to a pragmatic conception of the term "foundation" rather than simple zeroing. In other words, this means seeking the foundation on the ground of the practice and justifications that accompany its formation, persistence, and evolution.

Rorty would most likely say that this point of view inclines too much towards a sort of metaphysics of praxis. Provided that the word "metaphysics" is a very slippery one, I believe that the notion of "pragmatic foundation," as I quickly outlined it, is necessary to account for several qualifying aspects of Rorty's "liberal utopia." First, I do not see how else one could read its ethnocentrism, which assigns the historical-cultural context a solidity that no petitio principii can easily circumvent. Moreover, it would otherwise be difficult to understand all those "ethically-qualifying concepts" already mentioned - conversation, dialogue, solidarity, and finally, anti-authoritarianism which Curtis rightly defines in his book Defending Rorty. Pragmatism and Liberal Virtue (2015) as a "super virtue" that supports "the civil virtue of irony." To say that antiauthoritarianism is a virtue means to give value to a moral skill, but one that finds in Rorty historical-philosophical justifications and that, therefore, can "work" as a supporting ground for a series of socio-political practices that safeguard the primary 
value of individual freedom. I am convinced that it would be unfair to associate this last aspect of Rorty's thought with the defense of an unbridled neo-liberalism, as various interpreters tend to do, including Fraser (1997), with her comments on Rorty's intervention on feminism. Nevertheless, I confirm my preference for the idea of "radical democracy" put forward by Dewey. The discriminating point lies in Dewey's explicit reference to social justice, which I am not willing to bypass (in fact, these references by Dewey are limited to his production of the 1930s).

In this regard, I agree with Shusterman on seeing in Dewey a tighter commitment to the articulation of the individual-society relationship that, unlike for Rorty, is not likely to be unbalanced in favor of individuality. However, I would add that, although many pages of Rorty imply the individualist risk, unlike Shusterman, I believe that he also proposed some appreciable antidotes: first of all, the concept of solidarity, which is one of the cornerstones of his thinking. I tried to discuss this aspect, arguing that, especially in Contingency, Irony, and Solidarity, just starting from the narrative model of personal identity that he proposes, solidarity is configured as a "destination" of individuality. Narrating one's personal history is tantamount to seeking the recognition of others and, finally, trying to "accommodate" one's own identity with one's relationship with others. In short, one could count Rorty among the representatives of the so-called "solidarity individualism" rather than label him as a liberalist perched on the defense of individuality. I believe that Rorty's important novelty concerning traditional foundationalism - liberal or not - lies in his insistence that ethical and political projects should consider the relationship between the aesthetic sphere and the social sphere. The emphasis on self-realization seems to me to go in this direction, especially if we consider that this concept typically dates back to Emerson, whom Rorty does not hesitate to count among the founding fathers of pragmatism. As we know, Emerson's individualism has an instrumental value compared to his battle against authoritarianism, and yet it is expressed in a continuous dialectic with the attention to the value of the community.

In conclusion, thanking Curtis for having paid attention, as Bella also did, to my discussion of Peirce's Tychism, I tried to enhance a "new pragmatic anthropology" to build on some of Rorty's suggestions. I do not have much to add to Curtis' comments on this subject. I just want to confess that I did not dwell on Rorty's hasty references to Tychism in the text cited by Curtis, The Continuity between the Enlightenment and 'Postmodernism,' simply because I chose to exercise the principle of charity but, this time, not in the sense of the Quine-Rorty line, but the exquisitely Christian sense... In a few words, finding those references completely off-track, I avoided raging on a few lines, preferring instead to recall Peirce to suggest how the dialectic between chance and law implied by his Tychism can contribute to confer to the notion of chance the meaning of an indeterminate/ambiguity that opens the space of normativity.

I am aware that I have responded far from exhaustively to the critical questions addressed to me. I hope to reap the benefits in the near future, again thanking Bella, Curtis, and Višňovský for their generosity. 


\section{BIBLIOGRAPHY}

CALCATERRA Rosa M., (2003), Pragmatismo: i valori dell'esperienza. Letture di Peirce, James e Mead, Roma, Carocci.

CAlCATERRA Rosa M. (ed.), (2011), New Perspectives on Pragmatism and Analytic Philosophy, Amsterdam and New York, Rodopi.

CURTIS William, (2015), Defending Rorty. Pragmatism and Liberal Virtue, New York, Cambridge University Press.

DEWEY John, (1925/1981), Experience and Nature. The Later Works of John Dewey, 1925-1953, vol. 1, edited by Jo Ann Boydston, Carbondale, Southern Illinois University Press.

FRASER Nancy, (1997), "Structuralism or Pragmatism? Theory of Discourse and Politics of Feminism," in Justice Interrupts: Critical Reflections on the 'Post-Socialist' Condition, New York, Routledge, 201-21.

RORTY Richard, (1979), Philosophy and the Mirror of Nature, Princeton, Princeton University Press. [PMN].

RORTY Richard, (1989), Contingency, Irony, and Solidarity, Cambridge, Cambridge University Press. [CIS].

\section{AUTHOR}

\section{ROSA M. CALCATERRA}

Università Roma Tre

rosamaria.calcaterra[at]uniroma3.it 